\title{
Packaging type and their effects on the chemical and microbial quality of Sudanese white cheese (Gibna bayda)
}

\author{
Nazar Abdualaziz EINasri`, Samah Omer Sirag and Hassan Elsiddig Hag Elsafi \\ School of Health Sciences, Ahfad University for Women, Sudan.
}

Accepted 22 November, 2012

\begin{abstract}
The study was based on surveying ten samples of Sudanese white cheese packaged in two different containers (plastic and metal), collected from different supermarkets in Khartoum state. The comparison of chemical composition and microbial count was done. The experimental results showed that the average ash content, moisture, acidity, $\mathrm{pH}$, and total solid content means were $7.00 \pm 2.73$, $45.00 \pm 4.81,0.85 \pm 0.12,5.72 \pm 0.25$ and $45.00 \pm 10.63 \%$, respectively for cheese samples packaged in plastic containers while for samples packaged in metal containers, the values were $5.50 \pm 1.11,52.06 \pm$ 9.18, $1.85 \pm 0.41,5.06 \pm 0.33$ and $55.00 \pm 9.35 \%$ for ash content, moisture, acidity, $\mathrm{pH}$, and total solid content, respectively. The average chemical properties showed significant differences between the samples packaged in the two types of containers $(P \leq 0.05)$. The logarithm counts of total bacteria, yeasts and moulds for the samples packaged in plastic containers were found to be $8.86 \pm 4.80$ and 0.12 \pm 0.16 , respectively. On the other hand, the logarithm counts of total bacteria, yeasts and moulds for the samples packaged in metal containers were found to be $13.86 \pm 3.61$ and $015 \pm 0.09$, respectively. A clear significant differences between the samples packaged in the two types of containers $(P \leq 0.05)$ was found. There was no significant correlation between the total bacteria counts and the moisture content of the samples packaged in plastic and metal containers $(P \leq 0.05)$. The total bacterial count of the samples packaged in plastic and metal containers showed significant correlation to the $\mathrm{pH}$ value of the cheese samples collected from the supermarket $(P \leq 0.05)$.
\end{abstract}

Key words: Sudanese white cheese, average ash content, microbial count, moisture.

\section{INTRODUCTION}

Cheese is known as a complete nutritious food product and excellent source of many key nutrients, suitable for many ages. It is rich in protein and minerals such as calcium, there are different types of cheese: soft cheese, semi hard and hard cheese, the difference in these types is mainly due to water content or water activity and the methods and technology for cheese making (Pantaleao et al., 1990).

Pervious study mentioned that the cheese traditionally produced in Sudan is a white-brined variety known locally as Gibna bayda "white cheese" and it is widely consumed

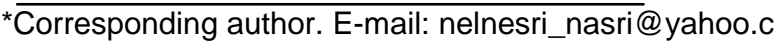

by people of all socioeconomic classes; most of it is made in houses and some private farm. Recently, due to increase of population, the cheese industry has become a common sight without supervision or quality. Sudanese white cheese is delivered to the market immediately after processing, under inadequate conditions, poor handling technique, inappropriate packaging materials and lack of adequate storage facilities, however, it seems that essential dairy products including cheese must be safe, acceptable and meet consumer's satisfaction (Khalifa, 1989; Ibrahim, 2003; Osman, 2008). As a result, cheese production must be protected from pathogenic and spoilage microorganisms, as well as from decaying both on the sites of production and consumption (Scott, 1986). Different factors influence the quality of white cheese 
and therefore its nutritive value, these factors include: composition of food materials, the nature of the compounds, the type of packaging system and the preservative added (Dueruet et al., 2001). Proper packaging method is very important for chemical, physical and microbial quality of white cheese. Microorganisms present in dairy products (fermented milk, cheese) belong to three groups; those responsible for transmission of food borne diseases (pathogens); others that may cause defects in dairy products and the ones that produce desirable flavour and physical characteristics. Dairy products are the major vehicle for transmission of human diseases such as Brucellosis, Salmonellosis and Tuberculosis.

Unless milk used for cheese processing is pasteurized or otherwise treated to destroy pathogens, pathogenic or toxin producing organisms present in raw milk could be found in cheese. These organisms may find their way into cheese as a result of environmental contamination during processing and packaging. The objectives of this study were to determine the effects of two packaging methods on the quality of Sudanese white cheese and to investigate the correlation between chemical and microbial parameter of Sudanese white cheese and type of packaging.

\section{MATERIALS AND METHODS}

The quality of white cheese including chemical and microbial characteristics which are affected by several factors were studied. In this study, five samples were chosen according to packaging in plastic container and five samples according to packaging in metal containers.

\section{Moisture content}

Moisture content was determined by the method of Association of Official Analytical Chemists (AOAC) (1990). Two grams of the sample were dried in an oven at 103 to $105^{\circ} \mathrm{C}$ for $24 \mathrm{~h}$, percent moisture content was calculated using the following formula:

$$
\text { Moisture content }=\frac{\text { Weight loss }(\mathrm{g})}{\text { Weight of the sample taken }} \times 100
$$

\section{pH measurement}

$\mathrm{pH}$ meter $(\mathrm{HACCH}, 1011)$ was used to measure the $\mathrm{pH}$ of cheese sample, where $\mathrm{pH}$ meter was calibrated with 4.00, 7.00, and 10.01 buffer solutions. Approximately $20 \mathrm{~mL}$ of the suspension was poured into a small glass beaker. The $\mathrm{pH}$ and temperature probes were suspended in the liquid until the $\mathrm{pH}$ meter indicated a stable reading.

\section{Total solid content}

Total solid content of the cheeses were determined by using ovendrying method describe by AOAC (1990), where the difference in weight before and after drying for $4 \mathrm{~h}$ at $100^{\circ} \mathrm{C}$ gives the results of solid content.

\section{Ash content}

Ash content was determined according to the method of AOAC (1990). One gram of defatted sample was ignited at $500^{\circ} \mathrm{C}$ in a muffle furnace for $2 \mathrm{~h}$ until a black color appeared. After cooling in desiccators, they were weighed. The difference in weight before and after burning process gives the percent ash content obtained using standard formula:

Ash $\%=\frac{\text { Weight of ash }}{\text { Weight of sample }}$

\section{Acidity}

The method describe by Foly (1974) was used to determine the titratable acidity, where $3 \mathrm{~g}$ cheese was weighed and crushed with $10 \mathrm{ml}$ water in porcelain mortar. This solution was transferred into an Erlenmeyer flask; 5 drops phenolphthalein was added and titrated with $0.1 \mathrm{~N} \mathrm{NaOH}$ to the first permanent color change of pink.

$\%$ Acidity $=\mathrm{NaOH}$ amount $\times 0.009 \times 100 \quad($ for $0.1 \mathrm{~N} \mathrm{NaOH}$ )

Cheese amount

\section{Microbiological analysis}

Ten grams of white cheese were added to $90 \mathrm{ml}$ of $2 \%$ sterile sodium citrate and blinded for $1 \mathrm{~min}$. Then, $1 \mathrm{ml}$ from the mixture was transferred with sterile $1 \mathrm{ml}$ graduated pipette to $9 \mathrm{ml}$ sterile normal saline in a test tube and mixed using another sterile pipette of $1 \mathrm{ml}$ of dilution that was prepared and transferred in a second test tube (Reuter, 1985).

\section{Preparation of the media}

All media were obtained in dehydrated forms and prepared according to the manufacturer's instruction (Oxoid, Basingstoke, Hampshire, UK).

\section{Types of media}

\section{Plate count agar}

This was used for the total bacterial count. The medium was prepared by suspending $7 \mathrm{~g}$ of powder in $250 \mathrm{ml}$ of distilled water, then boiled until dissolved completely and sterilized by autoclaving at $121^{\circ} \mathrm{C}$ at 15 pounds pressure for $15 \mathrm{~min}$.

\section{McConkey agar}

This medium was used for isolation of Enterobacteriacea. The medium was prepared by dissolving $4.7 \mathrm{~g}$ of McConkey agar in 250 $\mathrm{ml}$ of distilled water, then boiled until dissolved completely and sterilized by autoclaving at $121^{\circ} \mathrm{C}$ at 15 pounds pressure for $15 \mathrm{~min}$.

\section{Malt extract agar}

This medium was used for the count of yeast and moulds. The medium was prepared by dissolving $12.5 \mathrm{~g}$ of Malt extra agar in 250 
Table 1. Chemical composition of tested samples $(\mathrm{N}=10)$.

\begin{tabular}{cccccc}
\hline Sample & Ash (\%) & Moisture (\%) & Acidity (\%) & pH & Total solid content (\%) \\
\hline $1^{*}$ & 10.3 & 37.5 & 1.026 & 5.66 & 55.0 \\
$2^{*}$ & 10.0 & 49.0 & 0.99 & 5.31 & 30.0 \\
$3^{*}$ & 5.0 & 45.0 & 0.81 & 5.25 & 40.0 \\
$4^{*}$ & 5.0 & 47.5 & 0.684 & 4.96 & 55.0 \\
$5^{*}$ & 5.2 & 37.5 & 0.756 & 5.21 & 45.0 \\
$6^{* *}$ & 5.0 & 60.0 & 2.04 & 5.20 & 65.0 \\
$7^{* *}$ & 5.0 & 50.0 & 2.50 & 5.12 & 65.0 \\
$\mathbf{8}^{* *}$ & 7.5 & 57.5 & 1.50 & 5.24 & 50.0 \\
$\mathbf{9}^{* *}$ & 5.0 & 58.1 & 1.65 & 5.29 & 45.0 \\
$\mathbf{1 0}^{* *}$ & 5.0 & 57.5 & 1.51 & 4.20 & 50.0 \\
\hline
\end{tabular}

${ }^{*}$ Packaged in plastic containers, ${ }^{* *}$ packaged in metal containers, ${ }^{* * *}$ the results are average of triplicate samples.

$\mathrm{ml}$ of distilled water, then boiled until dissolved completely and sterilized by autoclaving at $121^{\circ} \mathrm{C}$ at 15 pounds pressure for $15 \mathrm{~min}$.

\section{Mannitol salt agar}

This was used for the Staphylococcus aureus count. The medium was prepared by suspending $27.7 \mathrm{~g}$ in $250 \mathrm{ml}$ of distilled water, then boiled until it dissolved completely and sterilized by autoclaving at $121^{\circ} \mathrm{C}$ at 15 pounds pressure for $15 \mathrm{~min}$.

\section{Violet red bile lactose agar}

This medium was used for isolation of coliform. The medium was prepared by dissolving $4.7 \mathrm{~g}$ of Violet red bile lactose agar in $250 \mathrm{ml}$ of distilled water, then boiled until it dissolved completely and sterilized by autoclaving at $121^{\circ} \mathrm{C}$ at 15 pounds pressure for $15 \mathrm{~min}$.

\section{Gram stain}

With sterilized loop, a drop of water was placed on clean slide and mixed with a loop full of culture growth and spread to form a thin film. The film was allowed to air dry and fixed by flame, then stained with crystal violet for $30 \mathrm{~s}$, washed, covered with Gram's iodine and allowed to act for $30 \mathrm{~s}$, washed, decolorized with $96 \%$ alcohol till the alcohol dripping from the slide showed faint colour, then rinsed with water and counter stained with safranin for $30 \mathrm{~s}$ and then rinsed with water, blotted dry, and examined under the oil objective (×100) (John and Booth, 1983).

\section{Data analysis}

The data of the present study were analyzed statistically using One Sample t-Test and Regression for Curve Estimation then the least significance differences between the samples were used to determine the differences between means. The analysis was carried out using Statistical Package for Social Sciences (SPSS) 12.0.

\section{RESULTS}

Table 1 shows the chemical composition of cheese samples to be $10.3 \%$ ash for cheese packaged in plastic containers while a $5 \%$ ash was reported for cheese packaged in metal. The average moisture content revealed a value of $(48.75 \pm 7.9)$ for all cheese samples. The average acidity of cheese samples was $1.35 \pm 0.60$, with a range from 0.63 to $1.03 \%$ (Table 1) for cheese sample packaged in plastic containers. The average of total solids content showed a value of $50.0 \pm 10.8$ for all cheese samples collected from markets in Khartoum state (Table 1). Values of 30 to $55 \%$ were obtained for samples packaged in plastic container, while total solid content for cheese sample packaged in metal container showed higher value (51 to 65\%) compared to that packaged in plastic.

The mean log counts of total bacterial count (TBC) were found to be $11.17770 \pm 4.69329$ for the cheese samples collected from super market (Table 2). The maximum values of total bacterial counts for cheese packaged in plastic containers and metal containers were 14.40 and 18.76 , respectively while the minimum values were 4.46 and 12.12, respectively. The mean counts of yeast and mould of the white cheese collected from supermarket was $0.1360 \pm 0.12501$. The maximum values of yeast and mould counts for cheese packaged in plastic containers and metal containers were 0.30 and 0.24, respectively. The mean log count of Enterobacteriacae was found to be $0.2540 \pm 0.0 .53897$ for the cheese samples collected from super market. Correlation between TBC, and moisture content of cheese packaging methods showed no significant correlation $(P \geq 0.05)$ (Figure 1), while the total bacterial count of the samples and $\mathrm{pH}$ showed significant correlation to the packaging system $(P \leq 0.05)$ (Figure 2$)$.

\section{DISCUSSION}

\section{Ash content}

The average ash content values were $(6.25 \pm 2.12 \%)$ for all cheese samples. Values of $10.3 \%$ were reported for 
Table 2. TBC, yeasts and moulds, enterobacteriacae, Staphylococcus aureus, and coliform bacteria logarithm counts.

\begin{tabular}{cccccc}
\hline Sample & $\begin{array}{c}\text { TBC } \\
\text { plate } \\
\text { count Agar }\end{array}$ & $\begin{array}{c}\text { Yeast and } \\
\text { mould } \\
\text { malt extra agar }\end{array}$ & $\begin{array}{c}\text { Enterobacteriacae } \\
\text { McConkey }\end{array}$ & $\begin{array}{c}\text { Staphylococcus aureus } \\
\text { mannitol salt agar }\end{array}$ & $\begin{array}{c}\text { Coliform } \\
\text { violet red bile agar }\end{array}$ \\
\hline $1^{*}$ & 6.16 & 0.28 & 0.00 & 0.00 & 0.00 \\
$2^{*}$ & 4.46 & 0.30 & 1.40 & 0.00 & 0.00 \\
$3^{*}$ & 5.54 & 0.00 & 0.00 & 0.02 & 1.00 \\
$4^{*}$ & 13.77 & 0.00 & 0.00 & 0.00 & 0.00 \\
$5^{*}$ & 14.40 & 0.00 & 0.00 & 0.00 & 0.00 \\
$6^{* *}$ & 14.62 & 0.00 & 0.00 & 0.00 & 0.00 \\
$7^{\star *}$ & 12.12 & 0.22 & 1.14 & 0.01 & 0.00 \\
$8^{\star *}$ & 8.88 & 0.16 & 0.00 & 0.00 & 0.20 \\
$9^{\star *}$ & 13.06 & 0.16 & 0.00 & 0.10 & 0.00 \\
$10^{\star *}$ & 18.76 & 0.24 & 0.00 & 0.00 & 0.00 \\
\hline
\end{tabular}

${ }^{*}$ Packaged in plastic container, ${ }^{* *}$ packaged in metal container, all results are an average of triplicate reading.



Figure 1. Correlation between TBC and moisture content of cheese samples packaged in plastic and metal containers.

cheese packaged in plastic containers while a $5 \%$ value was reported for cheese packaged in metal, which is similar to that reported by Osman et al. (2007). For Sudanese white cheese, the variation in the ash content probably rose from different salt levels used by different producers and the method of cheese manufacture; ash property is important in food system since it is a starting point to determine the minerals profile. However, the cheese results obtained were not far from those reported by Ceylan et al. (2003) and Warasama et al. (2006). There was no significant difference between values of ash contents $(P \leq 0.05)$ for both samples. In this study, there was no correlation between ash content and packaging methods.

\section{Moisture content}

The average moisture content revealed a value of ( 48.75 \pm 7.9) for all cheese samples collected from super markets in Khartoum State (Table 1). Lower values of moisture contents were recorded for the samples 


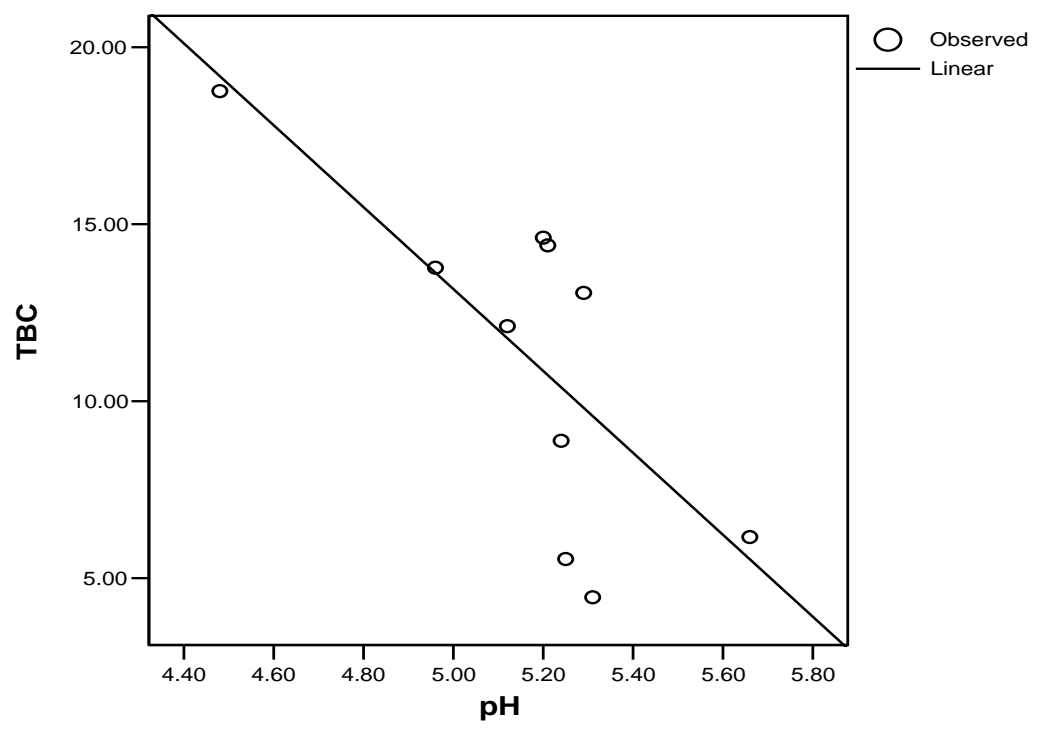

Figure 2. Correlation between TBC and $\mathrm{pH}$ of cheese samples packaged in plastic and metal containers.

packaged in plastic system (37.5\%), while the moisture content for samples packaged in metal containers ranged from (50.0 to $60.0 \%)$, the results are similar to that obtained by Ibrahim (2003) who showed that thirty samples of white cheese when examined had a mean average moisture content of $44.2 \%$, but the result are higher than that reported by Osman et al. (2008). Higher value of moisture content may be due to milk composition as concluded by Pearce and Gilles (1997) who reported that cheese made from milk with high fat contents tend to have higher moisture levels. These results indicate significant differences in moisture content of the samples $(P \leq 0.05)$. The increase in moisture contents of cheese samples from plastic to metal containers may be due to the variation in packing properties of plastic and metal substances. Frazier and Westhoff (1987) reported that the type packaging system applied has effects on the quality of cheese by minimizes the loss of moisture.

\section{Total acidity}

The average acidity of cheese samples was $1.35 \pm 0.60$, with a range from 0.63 to $1.03 \%$ (Table 1) for cheese sample packaged in plastic; these results were less than that reported by Ibrahim (2003) who reported varying values from 0.34 to $1.8 \%$. The variations among chemical composition and acidity of the cheese samples between different producers might be due to the lack of production process and to the variation in composition and properties of milk (Ceylan et al., 2003). Our results disagreed with Ali and Galal (2002) who reported values of 0.73 to $1.12 \mathrm{~g}$ lactic acid/100 g of cheese and acidity of 0.20 to $0.73 \%$, respectively. For cheese sample packaged in metal containers, the total acidity ranged from 1.51 to $2.5 \%$, which is higher than those reported for the samples packaged in plastic. Ahmed and Khalfa (1989) stated that the high acidity of cheese packaged in metal could be due the fact that the metal container may interact with the solution in which the cheese is suspend, resulting in hazardous effect because they cause a reaction with milk acids and this results to corrosion. Moreover, Hamed (1998) reported that the high acidity of raw cheese could be due to the fact that the packaging system, followed by storage temperature, activated the microflora of cheese to develop acidity as a result of lactose fermentation, since the cheese was stored at room temperature. These variations showed significant differences with regard to acidity content $(P \leq 0.05)$.

\section{Total solid content}

The values of total solid content (Table 1) indicated significant differences between the two types of packaging materials $(P \leq 0.05)$ but these values disagreed with previous studies by Osman et al. (2008) who reported a value ranged from 34.20 to $42.38 \%$ for white cheese, but not far from that reported by Osman et al. (2007) for Gibna bayda prepare by eight different traditional methods.

\section{$\mathrm{pH}$}

For $\mathrm{pH}$, our result was similar to that reported by Babekir (1987) who found that $\mathrm{pH}$ of white cheese samples stored in different conditions varied from 5.4 to 4.4 . We 
suggest that the difference in the $\mathrm{pH}$ of the two samples in two different packaging methods may due to the component of the container.

\section{Total bacterial counts}

The TBC result indicates significant differences between the two packaging materials $(P \leq 0.05)$. Ali and Galal (2002) found that total bacterial count was $6.2 \times 10^{6} \mathrm{per}$ gram for the fresh cheese and the count was decreased to $1.9 \times 10^{6}$ when Domiati cheese made from raw milk was stored for 4 months.

\section{Yeast and mould}

The differences between the maximum values of yeast and mould counts for cheese packaged in plastic containers and metal containers and the minimum values were 0.00 and 0.16 , respectively indicating significant differences between the two packaging materials ( $P \leq$ 0.05). Bonsancon et al. (1992) mentioned that yeast and mould are spoilage organisms resulting in flavour and texture deterioration including softening, discoloration and slime formation. Ibrahim (2003) found that yeasts constituted the primary microbial group of white cheese collected from Khartoum market, with counts ranging from 10 to 20 colonies per gram of cheese.

\section{Enterobacteriacae}

The maximum values of Enterobacteriacae for cheese packaged in plastic containers and metal containers were 1.40 and 1.14 , respectively, while the minimum values were 0.00 and 0.00 , respectively. This result indicates no significant differences between the two packaging materials $(P \geq 0.05)$. Growth of Enterobacteriacae in cheese was prevented by using fast-souring starter culture that rapidly converts lactose to lactic acid, thereby decreasing the $\mathrm{pH}$ in a short time to a level that inhibits their growth (Walstra et al., 1999).

\section{Staphylococcus aureus}

The log counts of $S$. aureus showed no records except 0.02 for one sample packaged in plastic containers. However, Allen et al., (1990) revealed that bulk raw milk contains appreciable amounts of toxigenic staphylococci and any stage in its processing which favours their growth will lead to toxin production.

\section{Coliform bacteria}

The log counts of these bacteria showed no record for both containers. Walstra et al. (1999) stated that coliform bacteria can grow only as long as sugar is available for fermentation because they cannot ferment lactic acid. The presence of coliform bacteria in dairy products is suggestive of unsanitary conditions or practices during production, processing and storage (Christen et al., 1992).

\section{Conclusion}

There were significant differences between values of ash contents, moisture content, average acidity, total solids, $\mathrm{pH}$ and the packaging system applied of the samples packaged in plastic and metal containers. These differences could be attributed to the variation between the natures of the two packaging materials, which may differ in the response of each material to the ambient temperature. The same significant differences were reported among the microbial quality between the samples packaged in plastic and metal containers. In this case, the changes induced by the differences between the two packaging materials as for the chemical quality may affect these variations in microbial quality.

\section{RECOMMENDATIONS}

1. Selection of the suitable packaging material that preserve desired chemical and physical quality of white cheese, as well as preventing adverse microbial activity is highly recommended. Moreover, the selected packaging materials must be quite suitable for the climatic and dominant storage conditions in our country.

2. Further studies are needed to determine the mechanism of how packaging material can affect the quality of cheese, the combination between the material, packaged system it is made up from and composition of cheese, since this result in very hazardous problems which are not known to many people. Steps should be taken to educate the community.

\section{ACKNOWLEDGEMENTS}

We would like to thank Prof. Gassim Badri, President of Ahfad University for Women for financing this work. Our pleasure is extended to Dr. Abu-Bakr Oro, Head of Ahfad Center for Science and Technology for the assistance during the practical studies which were carried in the Center's laboratories.

\section{REFERENCES}

Ahmed TK, Khalfa A (1989). The manufacture of white soft cheese (Gibna Beyda) from recombined milk. Sudan J. Anim. Prod. 2:63-69.

Ali S, Galal EA (2002). Effect of Milk pretreatment on the keep in Quality of Domiati cheese. Pak. J. Nutr. 1(3):U2-136.

Allen V, Stovall W, Harfer S (1990). Laboratory aspects of streptococcal food poisoning from Colby cheese. J. Food Prot. 23:271-274. 
AOAC (1990). Official of analysis. Association analytical chemist, Washington D.C.

Bonsancon N, Smct C, Chablier C, Cogan T, Condon S (1992). Study of yeast flora in cheese. J. Food Chem. 17:9-13.

Ceylan ZG, Turkoglu H, Dayisoylu S (2003). The microbiological and chemical quality of Skima cheese produced in Turkey. Pak. J. Nutr. 2(2):95-97.

Christen GL, Davison PM, McAllister J, Roth L (1992). Coliform and other indicator bacteria, 16th ed. In: Marshall RT, Standard Methods for Examination of Dairy Products.

Dueruet A, Carter B, Hamid D (2001). Effect of processing conditions on yield, chemical composition and sensory characteristics of white soft cheese. J. Trop. Med. Hyg. 25(1):122-136.

Hamed O (1998). The effect of processing conditions on yield, chemical composition and sensory characteristics of white soft cheese. M.Sc. Thesis, University of Khartoum.

Ibrahim A (2003). Studies on some characteristics of Sudanese white cheese. Sudan J. Vet. Sci. Anim. Husbandry 12:31-39.

Khalifa E (1989). The effect of salt concentration on the yield and chemical composition of Sudanese white cheese. M.Sc. Thesis, University of Khartoum.
Osman AO, El Owni, Omer IA (2007) Production of White Cheese (Gibna bayda) in Zalingei Area West Darfur (Sudan). Aust. J. Basic Appl. Sci. 1(4): 756-761.

Osman AO, El Owni, Omer IA (2008). Effect of Storage Period on Weight Loss, Chemical Composition, Microbiological and Sensory Characteristics of Sudanese White Cheese (Gibna Bayda) Pakistan J. Nutr. 7(1):75-80.

Pantaleao A, Moens E, O'Connor C (1990). The technology of traditional milk products in developing countries. FAO Animal Production and Health Paper 85. FAO, Rome, Italy. P 333.

Scott H (1986). Cheese Making Practice, $2^{\text {nd }}$ edition, J. Appl. Sci. pp. 23-28.

Warasama L, El Zubeir I, El Owni O (2006). Composition and hygienic quality of Sudanese white soft cheese in Khartoum Markets (Sudan). Int. J. Dairy Sci. 1(1):36-43. 